〈論文〉

\title{
環境試料中のけい光増白剂の 高速液体クロマトグラフィーによる定量
}

\section{Determination of Fluorescent Whitening Agents in River Water and Sediment by High Pressure Liquid Chromatography}

安 部 明 美*, 田中克 彦*, 深 谷 勝 久*, 竹下 三吉* Akemi ABE Katsuhiko TANAKA Katsuhisa FUKAYA Sankichi TAKESHITA Abstract

A method of determination of fluorescent whitening agents (FWA) in river waters and sediments by high performance liquid chromatography (HPLC) was studied.

Six kinds of FWA could be separated according to following conditions ; column: ODS SS $-10-$ B $4 \mathrm{~mm}$ i.d. $\times 250 \mathrm{~mm}$, mobile phase (a) $0.01 \mathrm{M} \mathrm{NaH}{ }_{2} \mathrm{PO}_{4}$-acetonitrile $(75: 25 \mathrm{v} / \mathrm{v})$, flowrate: $1.0 \mathrm{~m} \ell /$ $\min$.

FWA in the column effluent were monitored with fluorescent detecter $\left(E_{x}=358 \mathrm{~nm}, E_{m}=403 n m\right)$.

FWA in river waters were adsorbed on SEP PAC cartridge and eluted with methanol. FWA in river sediments were directly extracted by shaking with methanol successively three times.

Each extract was evaporated to dryness and dissolved in the solution of water-acetonitrile $(70: 30 \mathrm{v} /$ v) for HPLC.

From river waters and sediments of the Sagami river, two types of FWA (FWA I and FWA II), the same as used in the detergents, could be detected.

For the rapid quantitative analysis of FWA I and FWA II, it was found to be effective to use mobile phase (b) $0.1 \%$ tetraethyl ammonium perchrorate in water-acetonitrile $(70: 30 \mathrm{v} / \mathrm{v})$. Then peak heights were linear with FWA amounts in the range of $0 \sim 10$ ng for FWA I and $0 \sim 1$ ng for FWA II.

By the proposed method, FWA in river waters and sediments of the Sagami river were determined as follows; FWA I : $0.09 \sim 3.4 \mu \mathrm{g} / \mathrm{g}$ in sediments, FWA II $: 0.85 \sim 4.4 \mu \mathrm{g} / \ell$ in river waters, $0.14 \sim 10$. $7 \mu \mathrm{g} / \mathrm{g}$ in sediments.

KEY WORDS : fluorescent whitening agents

\section{1.はじめに}

けい光増白剤 (以下 FWA) は, 合成洗剤や繊維, 紙 などに添加して使用されて招り, 昭和55年度の国内生 産量は約 7,500 トン, 輸入量は約 800 トンであった。こ れらの FWA は, 合成洗片などの使用とともに, 環境 中に水系を通して排出されている。しかし, 例觉ば合 成洗剂には FWA は0.1〜0.5\%添加されているが1)主 成分である界面活性剤が 15 ～25\%含まれているのと比 較すると量的にかなり少ないらえ，光によるトランス 型とシス型の互変性があり, シス型ではけい光を失う2) などのために定量が困難である。このため環境中の FWA に関する報告3445) は少なく, 環境中に打ける
FWA の実態, 光分解, 生分解, 懸濁物質への吸着, 沈 降などについても医とんど明らかにされていない現状 である。

一方, FWA の安全性については, ジアミノスチルべ ン系の FWA の骨格構造が, 発がん性のある 4 -アミ ノスチルベンと似ているが, 各種の毒性試験の結果か らは，国内で使用されている FWA の毒性は問題がな

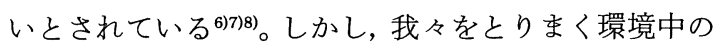
化学物質は多種多様であり, これらの分解生成物など を含む複合作用など未解明な点の多い現在，化学物質 による環境污染は，極力抑制されなければならない。 FWA は界面活性剂などと同様に, 身近に使用され, 広

* 神奈川県公害センター T241 横浜市旭区二俣川 1-87-1, Kanagawa Prefectural Environmental Center, 1-87-1, Futamatagawa, Asahi-ku, Yokohama, 241 Japan 
範に環境を污染する可能性のある物質である。

そこで今回, 環境中に存在する FWA の種類及び濃 度を把握するため, 環境試料からの FWA の抽出法及 び高速液体クロマトグラフィー（以下 HPLC）による 定性, 定量法について検討を行った。

\section{2. 実験方法}

\section{1 装}

使用した主な装置は次のと拈りである。

1 ）高速液体クロマトグラフ；日本分光工業侏製卜 ライロータ型 検出器；FP550

2 ）遠心分離機；秼佐久間製作所製

3 ) 振とう機; (秼杉山元医理器製

4) エバポレーター；東京理化器械製

\section{2 試薬}

1） FWA 標準物質；化成品工業協会及び日本チバ ガイギー侏から入手したものを，そのまま使用した。 Table 1 に化学構造式を示す。な抏, 純度は保証されて いないが，入手先からの情報により FWA I は $100 \%$, FWA II は90\%として定量値を補正した。

2) 過塩素酸テトラェチルアンモニウム；和光純薬 (侏)試薬特級

3）アセトニトリル，メタノール；和光純薬(侏液体 クロマトグラフ用

4) HPLC 用蒸留水; 蒸留水を直径 $47 \mathrm{~mm}$, 孔径 $0.45 \mu \mathrm{m}$ のメンブランフィルターでろ過したもの

5) セップパック $\mathrm{C}_{18}$ カートリッジ; 日本ウォー
ターズ陎製

\section{3 標準液の調製}

FWA I と FWA VIは，それぞれ0.1g ずつ精科し， ジメチルスルホキシドに溶かして全量を $100 \mathrm{~m} \ell と し ，$ FWA II, FWA III, FWA IV, FWA Vはそれぞれ0.1 $\mathrm{g}$ を蒸留水に溶解して全量を $100 \mathrm{~m} \ell$ とて，それぞれ $1,000 \mathrm{mg} / \ell$ 標準原液を調製した。これを水／アセト ニトリル $(70: 30 \mathrm{v} / \mathrm{v})$ の混合溶媒で順次希釈して, FWA II ついては0.1mg $/ \ell$, FWA I , FWA III,

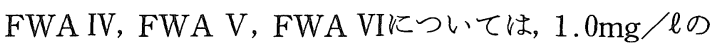
標準液を調製した。

\section{4 試料からの FWA の抽出}

1）水質試料

試料水に $0.1 \%$ になるよらに過塩素酸テトラェチル アンモニウム（TEAP）を加えて溶解し，その $20 \mathrm{~m} \ell を$ 正確に注射筒と先端にとりつけたセップパック $\mathrm{C}_{18}$ カートリッジにゆっくり通し, 次いでメタノール $3 \mathrm{~m}$ もを 2 回通して FWA を溶離した。

\section{2 ）底質試料，合成洗剂}

底質試料は風乾後， $2 \mathrm{~mm}$ メッンュのふるいを通過 した湿泥 2 ～ $10 \mathrm{~g}$ を, 合成洗剂は100mg をそれぞれ 100 $\mathrm{m} \ell$ 共栓付遠沈管に取り，これにメタノール $50 \mathrm{~m} \ell を$ 加光，振とう機を用いて20分間振とうしたのち，3,000 r.p.m で5分間遠心分離し，その上澄液を $200 \mathrm{~m} \ell$ そス フラスコにデカンテーションして移した。次いで, 再

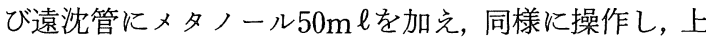
澄液を先のメタノール抽出液と合わせた。この操作を

Table 1 Chemical structures of fluorescent whitening agents

$\begin{array}{llll}\text { FWA III } & \mathrm{R} 1:-\mathrm{NH}-\mathrm{O} \text { - }\end{array}$


もら一度繰り返したのち, メタノール抽出液の全量を $200 \mathrm{~m} \ell$ と，その一定量をメンブランフィルターでろ 過した。

以上の操作で得られたメタノール抽出液（水質試料 の場合は全量, 底質試料の場合は $5 \mathrm{~m} \ell$ を分取)をエバ ポレーターを用いて蒝発乾固したのち, 水/アセトニ トリル混合溶媒 $(70: 30 \mathrm{v} / \mathrm{v})$ を正確に $1 \mathrm{~m} \ell$ 加えて溶 解し，これを HPLC 用試験溶液とした。

な报, 以上の操作は実験室の空際及び照明直下を避 けて行い*，ガラス器具は褐色のものを使用した。

\subsection{HPLC に上る分析条件}

HPLCによる分析条件を検討し，次のと打りとし た。

1) カラム; ODS SS $-10-\mathrm{B} 4 \mathrm{~mm} \phi \times 250 \mathrm{~mm}$

2) 移動相; (a) $0.01 \mathrm{MNaH}_{2} \mathrm{PO}_{4} /$ くトニトリ ル $(75: 25 \mathrm{v} / \mathrm{v}),(\mathrm{b}) 0.1 \% \mathrm{TEAP}$-水 $/$ アトニトリ ル $(70: 30 \mathrm{v} / \mathrm{v})$

$3 ）$ 検出波長; $\mathrm{E}_{\mathrm{x}}=358 \mathrm{~nm}, \mathrm{E}_{\mathrm{m}}=403 \mathrm{~nm}$

4 ) 流速 $; 1.0 \mathrm{~m} \ell / \mathrm{min}$

\section{3。結果と考察}

\subsection{FWA の定性分析}

移動相として0.01MNaH $\mathrm{PO}_{4} /$ とトニトリル （75:25v/v）を用い, Table 1 に示した 6 種類の FWA 標準試料を分離することができた。得られたク ロマトグラムをFig.1に示した。そこで, 河川水, 底 質, 合成洗剤中に含まれる FWA の種類を確認するた め, 上記の移動相を用いて分離したところ, Fig. 2 に示 すようなクロマトグラムが得られた。河川水では FWA II，底質ではFWA I 及び FWA II に相当する ピークが確認され, 特に濃度の高かった一部の底質試 料では, わずかに FWA VIに相当するピークの存在が 認められた。このうち, FWA II の標準試料と保持時間 の一致するピークについて波長走査を行い, 極大励起, けい光波長を求めたところ, $\mathrm{E}_{\mathrm{x}}=358 \mathrm{~nm}, \mathrm{E}_{\mathrm{m}}=430 \mathrm{~nm}$ となり，標準試料の場合と一致した。市販の合成洗剤 のうち, 合成洗剂AではFWA I と FWA II, 合成洗 剤BではFWA II とFWA VIが混合添加されている ことがわかった。これは中栄らの報告9と同様であっ た。したがって, 今回, 環境試料から検出された FWA は，主に合成洗剤に使用されているFWA I 及び

* 空際等の明所で行った予備実験では, 特に FWAI について，時間の経過とともにけい光強度の著し い減少がみられたので光の影響をなるべく避ける こととした。

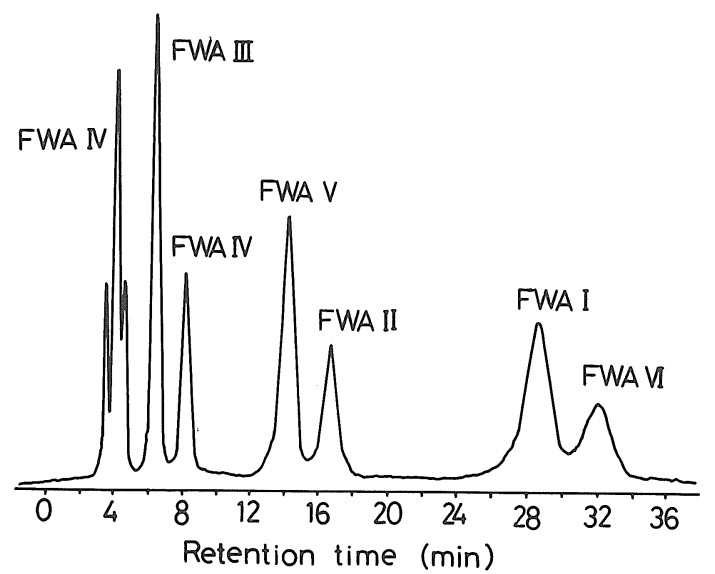

Fig. 1 Typical HPLC chromatogram of a standard mixture of fluorescent whitenig agents.

Condition-column; ODS SS-10-B (4mm i.d. $\times 250 \mathrm{~mm}$ ) eluent ; $0.01 \mathrm{M} \mathrm{NaH}{ }_{2} \mathrm{PO}_{4} / \mathrm{CH}_{3}$ $\mathrm{CN}(75: 25 \mathrm{v} / \mathrm{v})$

flow rate; $1.0 \mathrm{ml} / \mathrm{min}$ detecter; Jasco FP $550 \quad\left(\mathrm{E}_{\mathrm{x}}=\right.$ $358 \mathrm{~nm}, \mathrm{E}_{\mathrm{m}}=403 \mathrm{~nm}$ )

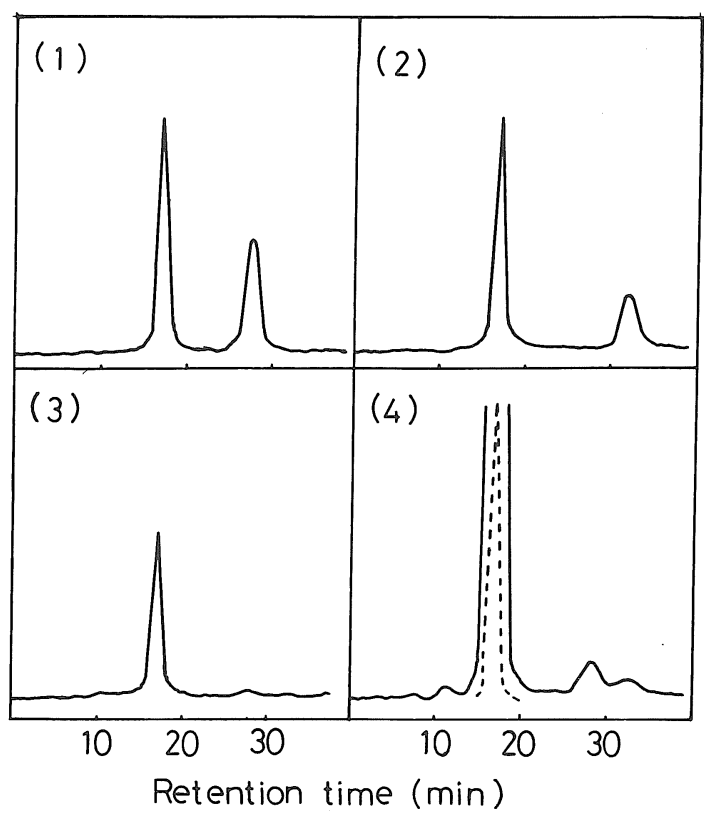

Fig. 2 HPLC chromatograms

(1)detergent A (2)detergent B (3)river water (4)river sediment 
FWA II であることがわかったので，この 2 種の FWA について定量的な検討を行った。

\subsection{FWA $の$ 定量分析}

FWA I と FWA II の定量分析には，展開時間を短 くするために, HPLCの移動相として(b) $0.1 \%$ $\mathrm{TEAP}$ 一水 $/$ アトニトリル $(70: 30 \mathrm{v} / \mathrm{v})$ を用いた。 そのクロマトグラムをFig.3に示した。この移動相 は，展開時間が短くてすむだけでなく，分析後にアセ トニトリルでカラムの洗浄を行うことにより, 目詰ま りやカラムの劣化を防ぐことができるなどの利点を有 することが確かめられた。

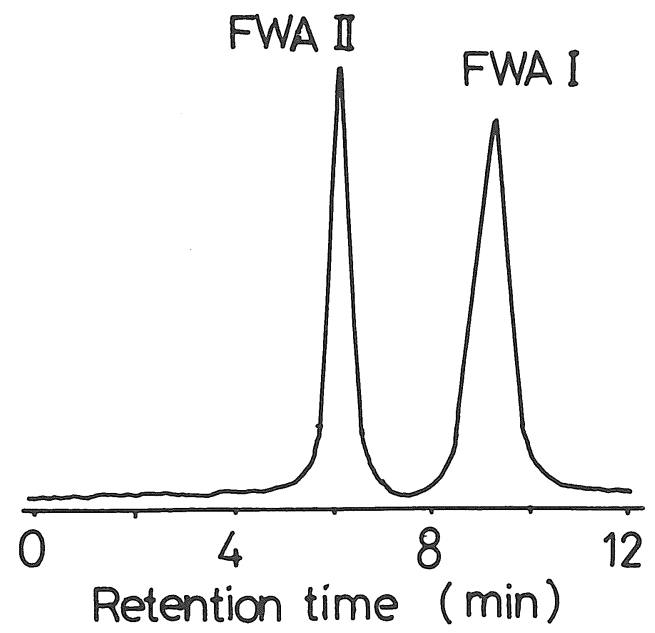

Fig. 3 HPLC chromatogram Conditions are the same as indicated in Fig. 1 except for the eluent ; $0.1 \%$ TEAPwater $/ \mathrm{CH}_{3} \mathrm{CN}(70: 30 \mathrm{v} / \mathrm{v})$.

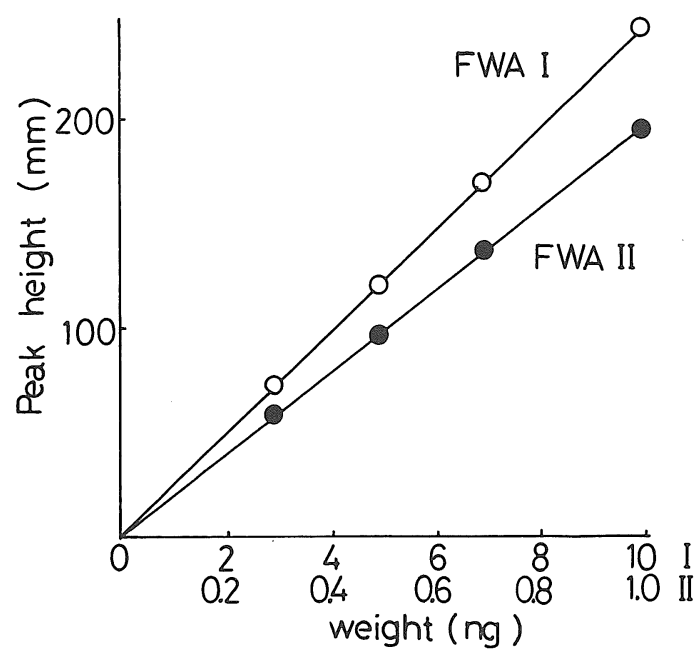

Fig. 4 Calibration curves.
ピーク高さによる検量線はFig.4に示したと打り であり, FWA I は $0 \sim 10 \mathrm{ng}$, FWA IIは $0 \sim 1 \mathrm{ng}$ の 範用で，それぞれ原点を通る直線性を示した。また， 再現性については, 同一カラムを用い, 注入量 $10 \mu \ell$ と して10回連続測定した場合の保持時間とピーク高さに ついて変動係数を求めたところ, FWA I では各々 2.2\%, 1.9\%,FWA IIでは1.8\%，3.1\%となり良好で あった。しかし，この移動相水分含量を変化させても FWA II と FWA Vを分離することができなかったの で, あらかじめ, (a) $0.01 \mathrm{MNaH}_{2} \mathrm{PO}_{4} /$ アトニトり ル $(75: 75 \mathrm{v} / \mathrm{v})$ の移動相を用いて定性的確認をする 必要がある。

\section{3 環境試料中の FWA の抽出}

1) セップパック $\mathrm{C}_{18}$ カートリッジ濃縮に括ける TEAP 濃度の影響

試料をせップパック $\mathrm{C}_{18}$ カートリッジに通水すると きに, FWA の対イオンとして添加する TEAP 濃度の 影響について検討したところ, Table 2 に示す結果を 得た。逆相系の $\mathrm{C}_{18}$ カートリッジでは, 対イオンを加光 ることによって陰イオンである FWA の吸着性が向 上することが予想されたが，メタノールによる溶離を 効率良く行うためには, TEAP は $0.1 \%$ 程度の添加が 適当であった。な扬，今回調査した河川水は，比較的 污濁の程度が低く，塩，懸濁物などの共存物質は少な いと思われるが，これらの多量に共存する試料では， FWA の $\mathrm{C}_{18}$ カートリッジへの吸着, 溶離に影響を及ぼ す可能性があると考兄られる。

2 ) 底質試料に扔けるメタノール抽出回数の検討

底質試料中の FWAをメタノールで抽出するとき の抽出回数と累積抽出率の関係を Fig. 5 に示した。底 質 $2 \sim 10 \mathrm{~g}$ (湿重量)を用いた場合，メタノール抽出は 原則として 3 回繰り返せば充分であった。

3 ) 添加回収実験

河川水にFWA I 及びFWA IIを $5 \mu \mathrm{g} / \ell$ たは $10 \mu \mathrm{g} / \ell$ になるよう添加して回收実験を行い, その回 収率を求めたところ, Table 3 に示寸結果を得た。また

Table 2 The effect of TEAP concentration on the extraction by the SEP PAC $\mathrm{C}_{18}$ cartridge

(\%)

\begin{tabular}{l|cc|cc}
\hline \multirow{2}{*}{ TEAP } & \multicolumn{2}{|c|}{ FWA I } & \multicolumn{2}{c}{ FWA II } \\
\cline { 2 - 5 } & $5 \mu \mathrm{g} / 1$ & $10 \mu \mathrm{g} / 1$ & $5 \mu \mathrm{g} / 1$ & $10 \mu \mathrm{g} / 1$ \\
\hline 0 & 82 & 77 & 78 & 64 \\
0.1 & 87 & 87 & 94 & 96 \\
0.2 & 85 & 77 & 86 & 99 \\
\hline
\end{tabular}




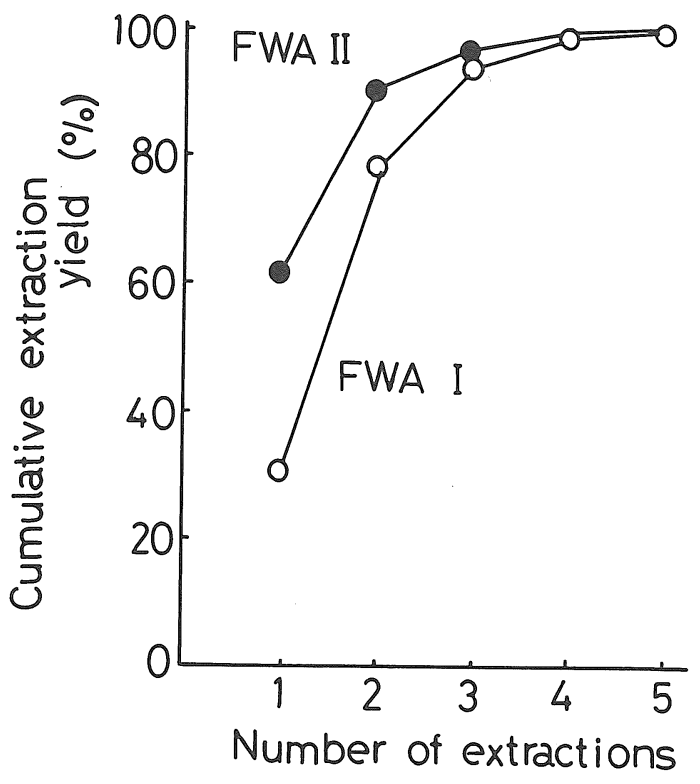

Fig. 5 Efficiency of methanol extraction.

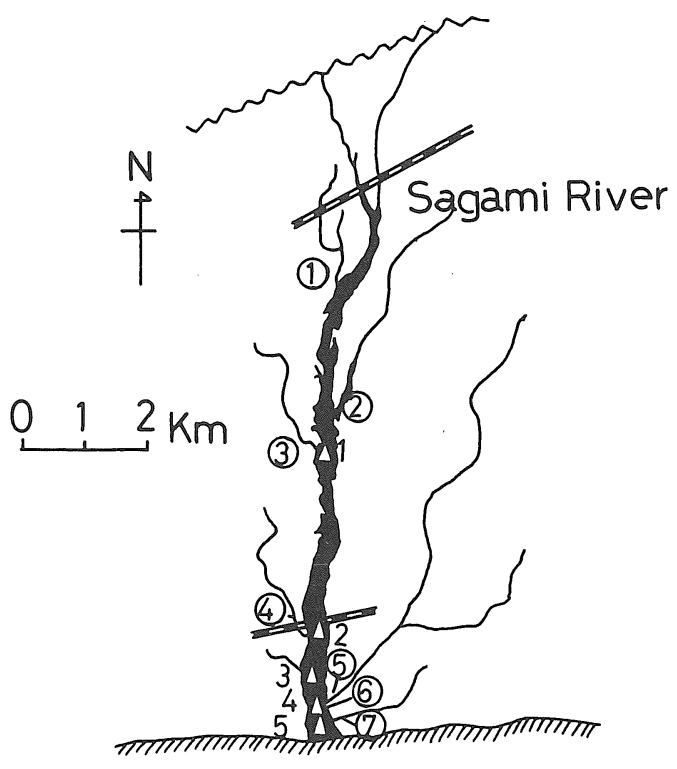

Sagami Bay

Fig. 6 Sampling points at the Sagami river.

(1) (7); river waters

$\triangle 1 \sim 5$; river sediments

Table 3 Recoveries of FWA added to river water samples

\begin{tabular}{ccccccccc}
\hline & \multicolumn{9}{c}{ FWA I } \\
\cline { 2 - 8 } No & $\begin{array}{c}\text { Present } \\
(\mu \mathrm{g} / \mathrm{l})\end{array}$ & $\begin{array}{c}\text { Added } \\
(\mu \mathrm{g} / \mathrm{l})\end{array}$ & $\begin{array}{c}\text { Found } \\
(\mu \mathrm{g} / \mathrm{l})\end{array}$ & $\begin{array}{c}\text { Recovery } \\
(\%)\end{array}$ & $\begin{array}{c}\text { Present } \\
(\mu \mathrm{g} / \mathrm{l})\end{array}$ & $\begin{array}{c}\text { Added } \\
(\mu \mathrm{g} / \mathrm{l})\end{array}$ & $\begin{array}{r}\text { Found } \\
(\mu \mathrm{g} / \mathrm{l})\end{array}$ & $\begin{array}{c}\text { Recovery } \\
(\%)\end{array}$ \\
\hline \multirow{2}{*}{3} & \multirow{2}{*}{ N.D } & 5.0 & 5.0 & 100 & & 5.0 & 9.8 & 99 \\
& & 10.0 & 9.0 & 90 & 5.2 & 10.0 & 13.9 & 95 \\
6 & \multirow{2}{*}{6} & 5.0 & 4.3 & 86 & & 5.0 & 5.8 & 94 \\
& & 10.0 & 8.8 & 88 & 1.2 & 10.0 & 10.7 & 97 \\
\hline
\end{tabular}

Table 4 Recoveries of FWA added to river sediments

\begin{tabular}{ccccccccc}
\hline & \multicolumn{9}{c}{ FWA I } & \multicolumn{4}{c}{ FWA II } \\
\cline { 2 - 9 } No & $\begin{array}{c}\text { Present } \\
(\mu \mathrm{g})\end{array}$ & $\begin{array}{c}\text { Added } \\
(\mu \mathrm{g})\end{array}$ & $\begin{array}{c}\text { Found } \\
(\mu \mathrm{g})\end{array}$ & $\begin{array}{c}\text { Recovery } \\
(\%)\end{array}$ & $\begin{array}{c}\text { Present } \\
(\mu \mathrm{g})\end{array}$ & $\begin{array}{c}\text { Added } \\
(\mu \mathrm{g})\end{array}$ & $\begin{array}{c}\text { Found } \\
(\mu \mathrm{g})\end{array}$ & $\begin{array}{c}\text { Recovery } \\
(\%)\end{array}$ \\
\hline 1 & 2.7 & 10.0 & 9.8 & 71 & 6.9 & 10.0 & 15.5 & 86 \\
4 & 4.1 & 10.0 & 13.3 & 92 & 14.3 & 10.0 & 23.4 & 91 \\
5 & 1.1 & 1.0 & 2.0 & 90 & 1.4 & 1.0 & 2.4 & 100 \\
\hline
\end{tabular}


底質 $2 \sim 10 \mathrm{~g}$ (湿重量) に FWA I 及び FWA II 1 $\mu \mathrm{g}$ または $10 \mu \mathrm{g}$ 添加し, 充分攪挥した後, 分析を行い 回収率を求めたところ Table 4 亿示す結果を得た。 FWA I では河川水が74 93\%, 底質が71 92\%, FWA II では, 河川水が $90 \sim 99 \%$, 底質が $86 \sim 100 \%$ と， ほ皃満足できる回収率を得ることができた。

\section{4 環境試料中の FWA の定量}

1980年～1981年にかけて，相模川河口域に抽いて河 川水及び底質を採取し，分析を行った。採取地点は Fig. 6 亿示したと扣りである。

採取した試料の FWA 含量を Table 5 及びTable 6 に示した。表からわかるように，すべての試料に执い てFWA IIはFWA I より濃度が高く，FWA IIでは 河川水中の濃度が $\mathrm{ppb}$ オーダーであるのに対し, 底質 中からは0.14 $10.7 \mu \mathrm{g} / \mathrm{g}$ 検出された。これは相模川 河口域の底質で直鎖アルキルベンゼンスルホン酸ナト リウム (LAS) が, $3.77 \sim 10.11 \mu \mathrm{g} / \mathrm{g}$ 検出されている 報告 ${ }^{10)}$ と比較すると, 割合高い值であり, FWA II が底 質中で比較安定であることを示唆している。また， FWA I とFWA IIでは, 水への溶解性, 光や塩素に対 する安定性に差があるため ${ }^{11}$ ，環境中でかなり異なっ た挙動をすると考えられるので，これらについては今

\begin{tabular}{ccc} 
Table & $\mathbf{5}$ & $\begin{array}{l}\text { Contents of } \\
\text { F W A i n } \\
\text { river waters }\end{array}$ \\
\hline No & $\begin{array}{c}\text { FWA I } \\
(\mu \mathrm{g} / 1)\end{array}$ & $\begin{array}{c}\text { FWA II } \\
(\mu \mathrm{g} / 1)\end{array}$ \\
\hline 1 & $<1.3$ & 3.4 \\
2 & " & 2.2 \\
3 & " & 4.4 \\
4 & " & 2.5 \\
5 & " & 1.5 \\
6 & " & 0.85 \\
7 & " & 4.2 \\
\hline
\end{tabular}

Table 6 Contents of FWA in the sediments

\begin{tabular}{cccr}
\hline No & FWA I & $\begin{array}{c}\text { FWA II } \\
(\mu \mathrm{g} / \mathrm{g} \text { dry wt. })\end{array}$ & I.L \\
\hline 1 & 0.67 & 1.6 & 11.6 \\
2 & 0.29 & 1.1 & 10.0 \\
3 & 0.34 & 0.81 & 5.0 \\
4 & 3.4 & 10.7 & 21.3 \\
5 & 0.09 & 0.14 & 1.6 \\
\hline
\end{tabular}

後検討する予定である。

\section{4.まとぬ}

環境試料中に存在する FWA の抽出法及び高速液 体クロマトグラフィーによる定性, 定量法の検討を行 い, 次の結果を得た。

1）高速液体クロマトグラフィーにより，6 種の FWA を分離することがでさたが，環境試料から検出 されたのはFWA I とFWA IIで, 主に合成洗剤に用 いられている種類と一致した。

2) FWA は，水質試料の場合はセップパック $\mathrm{C}_{18}$ カートリッジを用い，また底質試料の場合にはメタ ノールを加えて振とらする操作を行うことにより, 光 の影響を避けて迅速に抽出することができた。

3) 相模川河口域付近の河川水ではFWA II が $0.85 \sim 4.4 \mu \mathrm{g} / \ell$, 底質では FWAI が $0.09 \sim 3.4 \mu \mathrm{g} / \mathrm{g}$, FWA II が $0.14 \sim 10.7 \mu \mathrm{g} / \mathrm{g}$ 検出された。

謝 辞

本研究に際し, 試料の採取に御協力いただいた神奈 川県衛生研究所, 内藤昭治氏及び神奈川県試験研究連 絡協議会環境部会, 自然浄化能の利用分科会の方々に 深謝いたします。

（原稿受理：昭和58年 6 月 14 日）

\section{引 用 文 献}

1）化成品工業協会（1976）蛍光増白骭, p. 2.

2 ) 松尾昌本, 坂口忠夫 (1972) 4.4' (1.3.5一トリア ジンー2-イルアミノ) スチルベンー $2.2^{\prime}$ ージスル ホン酸ナトリウム誘導体の光退色, 日本化学会誌, 10, 1994-1996.

3 ）安部明美 吉見洋（1978）河川水に観測されるけ い光物質について, 水質污濁研究, 1（3）216-222.

4 ) M. Uchiyama (1979) Separation and Determination of fluorescent whitening agent and alkyl benzensulfonate in water. Water Res., 13 847-853.

5 ) R. Zinkernagel (1975) Fluorescent Whitening Agents, p. 129, Georg Thime Verlag, Stuttgart

6 ) B.J. Kilbey, L.G. Zetterberg, (1975) Fluorescent Whitening Agents, p.264, Georg Thime Verlag, Stuttgart.

7 ) Sturm, R.N., Williams, K.E. and Macek, K.J. (1975) Fluorescent Whitening Agents: Acute fish toxicity and accumulation studies. Water Res., 9 $211-219$.

8 ）日本石鹼洗剤工業会, 石けん・合成洗剤に関する 質問回答集, p.148.

9 ）中栄篤男, 森田まり子, 山中実（1980）高速液体 
クロマトグラフィーによる洗剤中のけい光増白㶡の

分析, 分析化学, 29, 69-73.

10）宇都宮暁子ら（1980）直鎖アルキルベンゼンスル ホン酸ナトリウム（LAS）に関する研究（第 1 報） 相模川河口域底質中の LAS について，衛生化学， 26, $159-166$.

11）シーエムシー（1976）ファインケミカル, p. 25.

\section{「水質污濁研究」次号（Vol.7 No.1）の予定目次}

\section{〈論文〉}

放線菌によるカビ臭の発生に及ぼす藻類の影響

杉 浦 則 夫他

沿岸海域に括ける海水の光学的性質およびそれらの季節変動

向 井 徹 雄他

誘導結合高周波プラズマ発光分析法による水中の微量ホウ素の定量

北 村 秀 樹他 タンパク質と塩素との水中に拉ける反応による有機塩素化合物の生成

名川吉 信他 水質の監視点位置の決定に関する一考察

一湖沼を例として一

松岡譲他

水質監視システムの費用便益分析

松岡譲他

〈講座〉

水質污濁現象の数理モデル

（その 4) 水供給計画モデルによる分析の方法について 